\title{
INFLUENCE OF FOLIAR FERTILIZATION ON YIELD AND GRAIN QUALITY
} OF CORN

\author{
Péter JAKAB ${ }^{1}$, LeVente Ódry ${ }^{1}$, TAMÁs Monostori ${ }^{1}$, Györgyi Csontos1, \\ MiHÁly SÁRVÁRI ${ }^{2}$, ISTVÁN KRISTó ${ }^{3}$, LEVENTE KOMAREK ${ }^{1}$ \\ ${ }^{1}$ University of Szeged, Faculty of Agriculture \\ Andrássy út 15, 6800 Hódmezővásárhely, Hungary \\ ${ }^{2}$ University of Debrecen, Faculty of Agricultural and Food Sciences and Environmental \\ Management \\ Böszörményi út 138, 4031 Debrecen, Hungary \\ ${ }^{3}$ Hungarian University of Agriculture and Life Sciences \\ Alsó kikötő sor 9, 6726 Szeged, Hungary \\ *Corresponding author: jakab.peter@mgk.u-szeged.hu
}

\begin{abstract}
We examined the influence of foliar fertilization on the yield and grain quality of corn in 2018. The experiment was set in three replications, random blocks on the area of Tangazdaság Ltd. in Hódmezővásárhely. The soil of the experiment was meadow chernozem. We sprayed out three different foliar fertilizer products individually and combined with each other as well, so there were six treatments and the control to be examined. The year 2018 was not favourable for corn production. In 2018 the amount of precipitation in the vegetative period of corn was lower by $70.5 \mathrm{~mm}$ than the average. The mounthly average temperature in the vegetative period of corn was higher by $4{ }^{\circ} \mathrm{C}$ than the average of several year. We evaluated the obtained data by single factor analysis of variance. We obtained $10.33 \mathrm{t} / \mathrm{ha}$ in control treatment, and with the foliar fertilization the yield ranged between 10.52-11.40 t/ha. The foliar fertilization products increased the yield of corn, but this difference was not significant. By the application of foliar fertilization, the crude protein and starch content of corn grain did not change significantly. Our scientific results showed, that the foliar fertilization has positive effect on the yield of corn and small effect on the examined grain quality parameters.
\end{abstract}

Keywords: corn, foliar fertilization, yield, crude protein content, starch content

\section{INTRODUCTION}

The genetical productivity of the newest corn hybrids is continuously growing. In order to utilize the potential productive capacity of hybrids as much as possible, the harmony of the agro-technical factors is necessary (Kovács and Sárvári, 2016).

The low average yield in corn production can be due to the fall-back of chemical fertilization; this is why the use of fertilizers must be increased in order to reach higher and more consistent amounts of crop (KOMAREK, 2007; SÁRVÁRI AND PEPÓ, 2014, PEPÓ, 2017; SÁRVÁRI, 2019; SÁRVÁRI ET AL., 2021).

Foliar fertilization is a highly efficient crop fertilization method since it favours the assimilation of the nutrients in the plant and consequently, the utilization of the nutrients applied with the fertilizer, thus increasing crop yields and quality (TEJADA AND GONZALEZ, 2004; ABBAS AND ALI, 2011; OSMAN ET AL., 2013).

In practice, foliar fertilizers are able to meet only a few percent of the main macroelement demands of plants. Foliar fertilization cannot provide nutrient uptake through the soil, just supplements it. The foliar fertilizer can get directly to the place of use, the leaf cells and can act immediately without the mediation of the soil. Nutrient uptake can be sustained even in drought, with little water. Under ideal conditions, the nutrient utilisation might reach 100\% (KÁDÁR, 2002). 
According to KÁDÁR (2008), the future spread of foliar fertilization must be grounded by comprehensive experimental research. Accurate, repeated small plot trials are necessary to clarify the factors influencing the effectiveness of foliar fertilizers and recommendations must be developed for consultation.

Nowadays, in order to achieve high yields, cultivated plants cannot always get enough microelements from the soil, therefore the importance of foliar fertilization increased. The timing is decisive for rapid and effective intervention to prevent yield loss or deterioration, and we can achieve yield increase and quality improvement as well. With the application of foliar fertilization, we can increase the resistance of corn against the ecological stress factors, diseases and pests as well (HOFFMANN ET AL., 2014).

Foliar fertilization had good effect in corn production on meadow chernozem soil, wich contains a lot of phosphorus and a few amounts of $\mathrm{Zn}$. The foliar fertilization products can decrease the yield fluctuation, and increase the yield amount. (JAKAB ET AL., 2014a; JAKAB ET AL., 2014b; JAKAB ET AL., 2016a; JAKAB ET AL., 2016b; JAKAB ET AL., 2016c; ZOLTÁN AND JAKAB, 2016; JAKAB AND KOMAREK, 2017).

\section{MATERIALS AND METHODS}

\section{Soil properties of the experimental field}

The research work has been carried out the experiment on the area of at the SZTE Tangazdaság Ltd. in Hódmezővásárhely. The soil was meadow chernozem, the reaction of which was nearly neutral $\left(\mathrm{pH}_{\mathrm{KCL}}\right.$ 7.17). Before setting the experiment, the soil analysis data showed that it had good nitrogen and very good phosphorus and potassium contents. The nitrogen content was determined based on the humus content. The $\mathrm{Zn}$ content was low (Table 1).

Table 1. Main properties of the experimental area

\begin{tabular}{|c|c|c|c|c|c|}
\hline $\begin{array}{c}\mathbf{p H} \\
(\mathbf{K C L})\end{array}$ & $\begin{array}{c}\mathbf{P}_{\mathbf{2}} \mathbf{O}_{\mathbf{5}} \\
(\mathbf{m g} / \mathbf{k g})\end{array}$ & $\begin{array}{c}\mathbf{K}_{\mathbf{2}} \mathbf{O} \\
(\mathbf{m g} / \mathbf{k g})\end{array}$ & $\begin{array}{c}\text { Humus } \\
(\mathbf{\%})\end{array}$ & $\begin{array}{c}\text { Soil } \\
\text { plasticity } \\
\text { value (K. }\end{array}$ & $\begin{array}{c}\mathbf{Z n} \\
(\mathbf{m g} / \mathbf{k g})\end{array}$ \\
\hline 7.17 & 336 & 620 & 3.39 & 48 & 1.76 \\
\hline
\end{tabular}

\section{Weather in the experimental year}

The year 2018 was not favourable for corn production. In 2018, the amount of precipitation in the vegetative period of corn was lower by $70.5 \mathrm{~mm}$ than the average (Table 2). The average temperature showed a positive deviation compared to the average of several years. The positive deviation of average temperature together with deficient precipitation had a negative effect on the development of corn, which resulted medium yields.

Table 2. The amount of rainfall in the vegetative period of corn in 2018

\begin{tabular}{|l||c||c||c||}
\hline Month & Rainfall $(\mathbf{m m})$ & $\begin{array}{c}\text { 50 years average } \\
\text { rainfall } \\
(\mathbf{m m})\end{array}$ & $\begin{array}{c}\text { Difference } \\
(\mathbf{m m})\end{array}$ \\
\hline \hline April & 12.4 & 39.9 & -27.5 \\
\hline May & 53.9 & 58 & -4.1 \\
\hline June & 85.2 & 75.3 & 9.9 \\
\hline \hline July & 51.4 & 58.7 & -7.3 \\
\hline August & 31.4 & 48.7 & -17.3 \\
\hline
\end{tabular}




\begin{tabular}{|l|c|c|c|}
\hline September & 16.5 & 40.7 & -24.2 \\
\hline $\begin{array}{l}\text { Total amount of } \\
\text { rainfall (mm) }\end{array}$ & $\mathbf{2 5 0 . 8}$ & $\mathbf{3 2 1 . 3}$ & $\mathbf{- 7 0 . 5}$ \\
\hline
\end{tabular}

\section{Main features of the agrotechnology applied}

The small plot experiment was set in three replications, organised as a random block. The size of each plot was $15 \mathrm{~m}^{2}$. The forecrop was winter wheat. Fall tillage involved deep ploughing at $30 \mathrm{~cm}$ depth in the experimental year. The sowing date was on $24^{\text {th }}$ of April. Plant density was 70.000/ha. The examined hybrid was DKC 4943 (FAO 390-410).

Foliar fertilization was applied once in 6-7 leaves stage of plants with a dose suggested by the manufacturers. The foliar fertilizers were put out with back-pack-sprayers. The applied products were the following:

- Algafix (microbiological biostimulator, that contains live algae which produce cytokinin, a plant hormone to help the shoot-growth of the plant),

- Amalgerol (product containing alga extract, plant extracts, plant essential oils and mineral oils), and

- Fitohorm Turbo Zn solution (containing Zn, the most important microelement for corn)

We applied these three products individually and combined with each other as well, so there were six treatments and the control plot. Apart from foliar fertilization, the parcels received the same agrotechnology We harvested the plots by hand. The protein and starch content were determined with Mininfra 2000 device. We evaluated the obtained data by single factor analysis of variance.

\section{RESULTS}

The yield of the control treatment was $10.33 \mathrm{t} / \mathrm{ha}$. With the application of foliar fertilization the yield varied between 10.52-11.40 t/ha. The foliar fertilization treatments increased the corn yield compared to the control, but it was not significant. We obtained the highest yield in the Algafix treatment (11.40 t/ha). We got high yield in Algafix + Fitohorm Turbo Zn (11.23 t/ha) and Amalgerol + Fitohorm Turbo Zn (11.35) treatments (Figure 1).

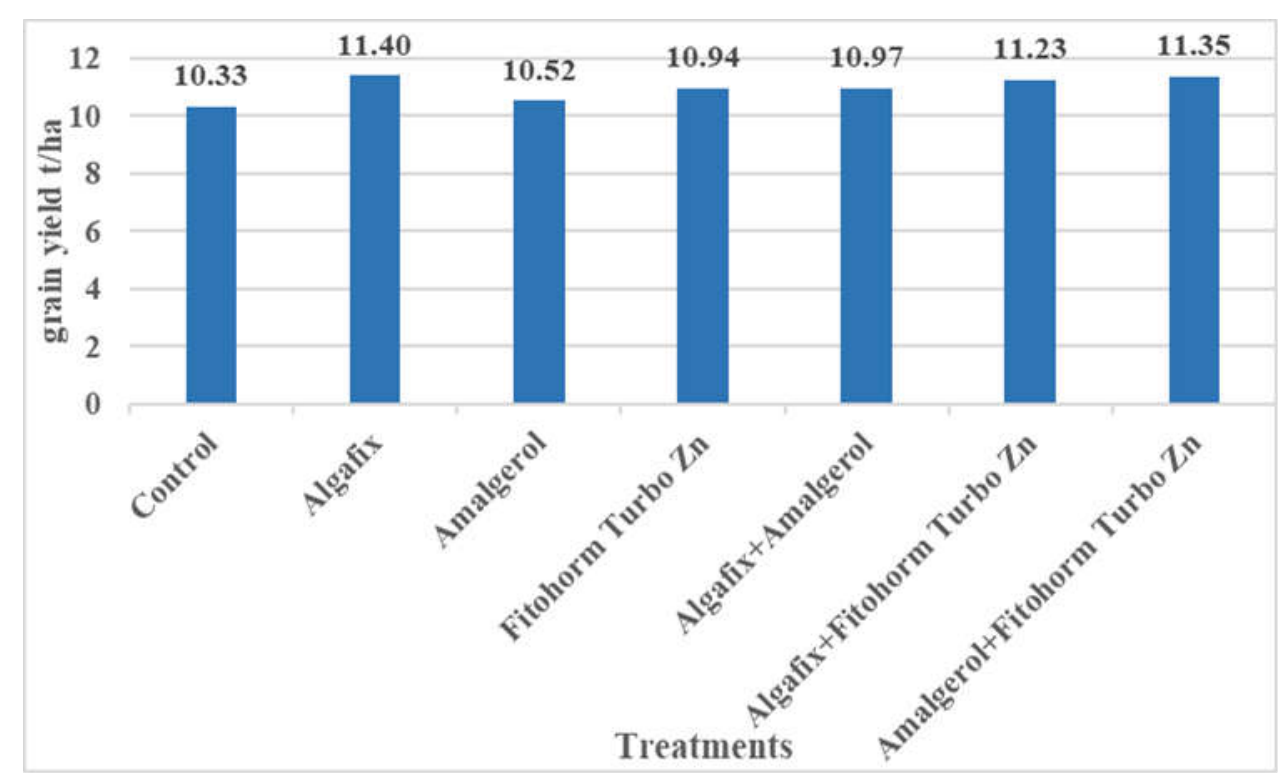

Figure 1. The yield of corn in control and different foliar fertilization treatments 
We examined the effect of foliar fertilization on some quality parameters of corn grain (protein and starch content).

The protein content of corn grain is relatively low (under 10\%). The grain protein content of control treatment was $7.8 \%$. Under the influence of foliar fertilization the protein content varied between $7.22-7.82 \%$. The maximum value of grain protein content was $7.82 \%$ in Algafix treatment.

Starch is in the highest amount in corn grain. The starch content of corn grain varied between $71.93-72.27 \%$. The starch content in control treatment was $71.93 \%$. The maximum value was $72.27 \%$ in Algafix+Fitohorm Turbo $\mathrm{Zn}$ treatment. The protein and starch content of corn grain did not change significantly (Table 3 ).

Table 3. The values of corn grain protein and starch content in different foliar fertilizer treatments

\begin{tabular}{|l|c|c|}
\hline \multicolumn{1}{|c|}{ Treatments } & Protein content (\%) & Starch content (\%) \\
\hline Control & 7.80 & 71.93 \\
\hline Algafix & 7.82 & 71.93 \\
\hline Amalgerol & 7.43 & 72.00 \\
\hline Fitohorm Turbo Zn & 7.74 & 71.83 \\
\hline Algafix+Amalgerol & 7.57 & 71.90 \\
\hline Algafix+Fitohorm Turbo Zn & 7.22 & 72.27 \\
\hline $\begin{array}{l}\text { Amalgerol+Fitohorm Turbo } \\
\text { Zn }\end{array}$ & 7.65 & 71.67 \\
\hline & & N.S. \\
\hline
\end{tabular}

\section{DISCUSSION}

We examined the effect of different foliar fertilizer products and their combination on the yield as well as protein and starch content of corn grain in 2018. The yield of the control treatment was $10.33 \mathrm{t} / \mathrm{ha}$. Compared to that, higher yields were measured in all treatments. The yield increase compared to the control, was not significant in either case. The foliar fertilizers applied individually resulted in 0.19 to $1.07 \mathrm{t} /$ ha surplus yield compared to the untreated parcel. The highest yield increase was achieved by Algafix treatment $(1.07 \mathrm{t} / \mathrm{ha})$. When the products were applied in combination, there was 0.64 to $1.02 \mathrm{t} / \mathrm{ha}$ surplus yield compared to the untreated parcel. The highest yield increase $(1.02 \mathrm{t} / \mathrm{ha})$ was measured in the treatments with Amalgerol+Fitohorm Turbo Zn.

The results of our studies are the same as those published by TEJADA ET AL. (2018) who also found that foliar fertilization increased the corn yield. The foliar fertilizer products had minimal effect on the protein and starch content of corn grain.

\section{REFERENCES}

Abbas, M.K., Ali, A.S. (2011): Effects of foliar application of NPK on some growth characters of two cultivars of roselle (Hibiscus sabdariffa L.). American Journal of Plant Physiology 6: 220-227.

Hoffmann, R.-Varga, Cs.-Karika, A. (2014): Levéltrágyázás a gyakorlatban. Agrárium. 24. (8): 69-72. 
Jakab, P., Komarek, L. (2017): The effect of foliar application on different fertilizers on technological and economical parameters of corn. Infrastructure and Ecology of Rural Areas, Krakow 3.(1): 923-934.

Jakab, P., Süli, Á., Nagy, P., Kristó, I. (2014a): The effect of foliar fertilization on the yield, chemical composition and nutrient value of corn. Lucrari Stiincifice Management Agricol. 16 (1): 202-205.

Jakab, P., Nagy, P., Kristó, I. (2014b): Environmentally friendly nutrient supply of corn. Review on Agriculture and Rural Development. 3 (1): 320-323.

Jakab, P., Zoltán, G., Komarek, L. (2016a): The effect of foliar fertilization on the yield and generative factors of corn. Review on Agriculture and Rural Development. 5 (1-2): 158-161.

Jakab, P., Komarek, L., Zoltán, G. (2016b): The study of foliar fertilization in corn production, In: Futó Z (szerk.). Kihívások a mai modern mezőgazdaságban. agyar Tudomány Napja Konferencia Kiadványa, Szent István Egyetemi Kiadó, Gödöllő, 197202.

Jakab, P., J.P. Szucsne, Süli, Á., Benk, Á. (2016c): Study of foliar fertilization on the yield, chemical composition and nutrient value of corn. Lucrari Stientifice Management Agricol. 18 (1): 123-126.

Kádár, I. (2002): Levéltrágyázás jelentősége és szerepe a növénytáplálásban. Az elméleti alapok összefoglalása. Gyakorlati Agrofórum. 12: 7-10.

Kádár, I. (2008): A levéltrágyázás jelentősége és szerepe a növénytáplálásban. Acta Agronomica Óváriensis. 50 (1): 19-27.

Komarek, L. 2007, A Dél-Alföldi Régió súlyának, szerepének alakulása a hazai agrártermelésben. COMITATUS: ÖNKORMÁNYZATI SZEMLE 17. (9): 52-64.

Kovács, P., Sárvári, M. (2016): The effect of some agrotechnical factors on the yield of corn hybrids with different genetic base. Növénytermelés. 65. (Supplement): 103-106.

Osman, E.A.M., E.L-Masry, A.A., Khatab, K.A. (2013): Effect of nitrogen fertilizer sources and foliar spray of humanic and/or fulvic acids on the yield and quality of rice plants. Advances in Applied Scientific Research 4: 174-183

Pepó, P. (2017): Role of agrotechnical elements in sustainable wheat and maize production. Columella - Journal of Agrotechnical and Environmental Sciences. 4. (1): 59-64. DOI: 10.18380/SZIE. COLUM.2017.4.1.59

Sárvári, M. (2019): Kukorica. In: Pepó P (szerk.). Integrált növénytermesztés 2. Alapnövények. Mezőgazda Lap és Könyvkiadó, Budapest 59-92.

Sárvári, M., Pepó, P. (2014): Effect of production factors on maize yield and yield stability. Cereal research Communications. 42. (4): 710-720. DOI: 10.1556/CRC.2014.0009

Sárvári, M., Jakab, P., Futó, Z. (2021): Hazánk szántóföldi növénytermesztése: A klímaváltozás hatásai mérsékelhetők, az eredményesség fokozható. Agrárunió 22 (3): 18-21.

Tejada, M., Gonzalez, J.L. (2004): Effects of foliar application of byproduct of thetwostep olive oil mill process on rice yield. European Journal of Agronomy. 21: 31-40

Tejada, M., Rodrigez-Morgado B., Paneque P., Parrado, J. (2018): Effects of foliar fertilization of a biostimulant obtained from chicken feathers on maize yield. European Journal of Agronomy. 96: 54-59.

Zoltán, G ., Jakab, P. (2016): Lombtrágya készítmények hatása a kukorica termésére és beltartalmára. In: Szalka Éva, Bali Papp Ágnes (szerk.), XXXVI. Óvári Tudományos Nap: Hagyomány és innováció az agrár- és élelmiszergazdaságban II. 335 p. Konferencia helye, ideje: Mosonmagyaróvár, Magyarország, 2016.11.10 

DOI: 10.14232/rard.2021.1-2.115-120

Mosonmagyaróvár: Széchenyi István Egyetem Mezőgazdaság- és Élelmiszertudományi Kar, 2016. 246-251.(ISBN:978-615-5391-79-8) 